\title{
Aa. Vv., Poètes et musiciens dans l'espace bourguignon. Les artistes et leurs mécènes
}

\section{Maria Colombo Timelli}

\section{(2) OpenEdition}

10 Journals

\section{Édition électronique}

URL : https://journals.openedition.org/studifrancesi/26007

DOI : $10.4000 /$ studifrancesi.26007

ISSN : 2427-5856

Éditeur

Rosenberg \& Sellier

\section{Édition imprimée}

Date de publication : 1 avril 2007

Pagination : 155

ISSN : 0039-2944

\section{Référence électronique}

Maria Colombo Timelli, « Aa. Vv., Poètes et musiciens dans l'espace bourguignon. Les artistes et leurs mécènes », Studi Francesi [En ligne], 151 (LI | I) | 2007, mis en ligne le 30 novembre 2015, consulté le 23 novembre 2021. URL : http://journals.openedition.org/studifrancesi/26007 ; DOI : https://doi.org/ 10.4000/studifrancesi.26007

Ce document a été généré automatiquement le 23 novembre 2021.

\section{(c)}

Studi Francesi è distribuita con Licenza Creative Commons Attribuzione - Non commerciale - Non opere derivate 4.0 Internazionale. 


\title{
Aa. Vv., Poètes et musiciens dans l'espace bourguignon. Les artistes et leurs mécènes
}

\author{
Maria Colombo Timelli
}

\section{RÉFÉRENCE}

«Publication du Centre Européen d'études Bourguignonnes ( $\mathrm{XIV}^{\mathrm{e}}-\mathrm{XVI}{ }^{\mathrm{e}} \mathrm{s}$.)» $\mathrm{N}^{\circ} 45-2005$, Rencontres de Dordrecht (23 au 26 septembre 2004), Poètes et musiciens dans l'espace bourguignon. Les artistes et leurs mécènes.

1 Quatre articles concernent la littérature en langue française.

2 Jelle KoOpMans (Poètes et polyphonistes: mondes de Molinet, pp. 73-80) ouvre de nouvelles perspectives sur le rapport entre musique, poésie et théâtre à la fin $d u x^{e}$ - début du $\mathrm{XVI}^{\mathrm{e}}$ siècle. Comme J.K. le montre clairement, Jean Molinet lui-même fait partie d'un cercle de poètes et musiciens qui s'échangent des poèmes et des lettres poétiques: les deux arts ne se séparent donc pas, comme le prétend la critique traditionnelle, avec Eustache Deschamps au XIV ${ }^{\mathrm{e}}$ siècle.

Isabelle RAGNARD (Les chansons d'étrennes aux XIV et XV siècles, pp. 105-127) étudie un répertoire significatif de 37 chansons d'étrennes, composées entre 1380 et 1440 environ; elle reconnaît deux périodes de composition, la première se terminant autour de 1420-30, des formules convenues, avec référence au calendrier et mention de la coutume des étrennes, l'expression de vœux (adressés à la dame aimée, à un protecteur, à un ou à des amis), l'allusion au contredon attendu. Malgré la rareté des pièces conservées, qui s'explique en partie par la fragilité des supports (des feuillets volants), la chanson d'étrennes est le témoignage d'une pratique sociale, et parfois de la valeur reconnue à une forme lyrique que des poètes tels qu'Eustache Deschamps, Christine de Pizan ou Charles d'Orléans ne dédaignèrent pas de pratiquer. 
4 Claudine LEMAIRE, Approche textuelle du rondeau 'L'homme armé' et du motet 'Anthoni usque limina' d'Antoine Busnoys. Analyse codicologique du manuscrit Bibliothèque Royale de Belgique, KBR 5557, pp. 165-189. Dans un premier volet, C.L. présente le poète-compositeur Antoine Busnoys (né vers 1420-30, mort en 1492, engagé par Charles le Téméraire), et propose une étude sémantique du rondeau L'homme armé, étonnante intrusion du monde laïque dans le domaine de la musique religieuse. La seconde partie consiste dans l'analyse et traduction française du motet latin consacré à saint Antoine, transmis par le même manuscrit KBR 5557.

5 Livia VISSER-FUCHS ('Le conte dont on chante': Burgundian Popular Ballads and Courtly Poems on the Earl of Warwick, pp. 191-235) étudie le contenu d'une série de textes poétiques, français et latins, composés dans les années 1470-71 et consacrés au comte de Warwick, figure de premier plan au centre d'une intense activité politique entre France, Angleterre et Bourgogne. Il s'agit d'une Ballade aux Franchoix, de la Response sur la dicte ballade, de quatre poèmes latins de Jean Miélot, de deux épitaphes satiriques (accompagnés de traduction en flamand et de deux ballades de réaction); tous les textes sont édités en annexe. 